\title{
Competitive Advantages of Shadow Banking Industry: An Analysis Using Porter Diamond Model
}

\author{
Arash Riasi \\ Institute for Financial Services Analytics, University of Delaware \\ 97 Amstel Ave., Apt. West 23, Newark, Delaware, 19711, United States \\ Tel: 1-302-898-6249_E-mail: riasi@udel.edu
}

Received: September 19, 2015 Accepted: October 122015 Published: November 1, 2015

doi:10.5296/bms.v6i2.8334 URL: http://dx.doi.org/10.5296/bms.v6i2.8334

\begin{abstract}
This paper tries to find out why shadow banking system has become so competitive in the global financial system and how it can be controlled. For this reason we use Porter's diamond model to find the competitive advantages of shadow banking. Based on the results of this study it can be concluded that factor conditions, chance and government do not contribute to the competitiveness of shadow banking industry. On the other hand the results suggested that related and supporting industries, firm strategy, structure and rivalry, and demand conditions contribute to the competitiveness of shadow banking industry. It is important to regulate the activities of shadow banking industry in order to prevent this industry from creating systemic risk.
\end{abstract}

Keywords: Shadow banking, Competitive advantage, Alternative financing, Porter Diamond model, Banking industry, Systemic risk 


\section{Introduction}

Every firm needs to obtain financing at some stage of its life cycle in order to be able to grow (Riasi, 2004; Riasi \& Amiri Aghdaie, 2013; Riasi, 2015; Riasi \& Pourmiri, 2015a; Riasi \& Pourmiri, 2015b; Riasi \& Asadzadeh, 2015). In a traditional financial system a firm is only able to obtain funding for its projects through banks and financial markets; but in a modern financial system there are some other financing channels available for the firms. Firms' financing channels in a modern financial system include banking and intermediation sector, financial markets (including capital markets, spot market, money market, derivatives market, Forex and interbank market), international sector, and alternative sector. Bank credit can have several advantages for firms and the economy. For instance, bank credit helps firms to create long-term relationships with banks; it also helps to facilitate corporate control mechanisms and possibly easier funding of start-up firms. Stock markets are also an important financing channel for several reasons: First, they offer a new form of investment in financial markets. Second, they have a positive influence on economic growth of countries (Allen et al, 2013). Third, equity markets reduce the cost of mobilizing savings and facilitate investments into the most productive technologies (Greenwood and Smith, 1997). Finally, stock market liquidity positively predicts growth, capital accumulation, and productivity improvements (Levine and Zervos, 1998). International capital raisings grew more than 4-fold between 1991 and 2008 (Gozzi et al, 2012); therefore international financial markets have become a very important financing channel for firms in growing economies. International financial markets are usually called the international sector. There are several motivations for issuing bonds and equities in international financial markets. Potential motivations for issuing bonds in international financial markets include risk management, price arbitrage, market completeness, barriers to nonresident investment onshore, and funding diversification (Black and Munro, 2010). Potential motivations for issuing equities in international financial markets are to avoid illiquid domestic markets, taxes, regulations, and the lack of suitable accounting and auditing systems (Gozzi et al, 2012). Small- and medium-sized firms do not have broad access to traditional financial systems and cannot easily obtain financing for their projects through banks and financial markets; therefore they have to find alternative financing channels for their projects (Allen et al, 2013). There are different types of alternative financing channels for a firm, including: retained earnings, loans from family and friends, loans from founders and managers, shadow banking system, trade credit, private credit agencies, leasing, credit card loans, investment funds, and private equity.

Shadow banking is growing at phenomenal rates in China and India and it is also becoming an important issue in some Western countries. The true size of worldwide shadow banking system may have been around $\$ 100$ trillion. According to IMF, in emerging market economies, overall shadow banking continues to grow strongly and shadow banking assets as a proportion of GDP have been expanded from 6 percent in 2002 to 35 percent in 2012 (International Monetary Fund, 2014). Shadow banking is predicted to grow further in the current environment of tighter bank regulations and low interest rates. Many indications point to the migration of some activities, such as lending to firms, from traditional banking to the 
non-bank sector. This paper tries to find out why shadow banking system has become so competitive in the global financial system and how it can be controlled. For this reason we use Porter's diamond model to find the competitive advantages of shadow banking.

\section{Shadow Banking System}

The term "shadow banking" was first introduced by McCulley (2007). The Financial Stability Board (FSB, 2011) defines shadow banking as "credit intermediation involving entities and activities outside the regular banking system". The majority of research studies identify shadow banking system to be less regulated than traditional banking system and claim that shadow banking lacks a formal safety net (e.g. Claessens \& Ratnovski, 2014). Other definitions of shadow banking industry focus on instruments (McCulley 2007; Mehrling et al, 2013) or markets (Gorton \& Metrick, 2012). The term shadow banking also refers to unregulated activities performed by regulated institutions. The meaning and the scope of shadow banking is a point of dispute in academic literature (Noeth \& Sengupta, 2011) but we can claim that shadow banking system is composed of: structured investment vehicles (SIVs), mortgage companies, investment banks, asset-backed commercial paper conduits, money market funds and etc. According to Singh (2010), shadow banking also includes hedge funds, pension funds, and insurance companies.

Since shadow banking institutions do not operate under meaningful regulatory constraints regarding the size of their liquidity buffers, the types of lending and investing which they can have, and the amount of leverage which they can use, they have escaped most regulatory limits and laws imposed on the traditional banking system (McCulley, 2009). Also since shadow banking system is less regulated than traditional banking system, regulatory arbitrage tends to increase the demand for shadow banking (Schwarcz, 2012). Therefore an increase in bank regulations will probably increase the demand for shadow banking. If shadow banking remains unregulated, it can cause systemic risks and risk of liquidity discontinuities to the financial system (Schwarcz, 2012). As an illustration of this, many believe that credit transformation in shadow banking system was a contributing factor to the asset bubble in real estate market before 2008 financial crisis. The recent financial crisis revealed that regulatory arbitrage and high financial risks are associated with risk management in shadow banking system (Claessens et al, 2012). Although shadow banking is a relatively new topic, many scholars have performed research on this topic (e.g. Acharya et al, 2013; Adrian \& Ashcraft, 2012; Adrian \& Shin, 2009; Gennaioli et al, 2013; Gorton \& Metrick, 2011 \& 2012; Schwarcz, 2012; Stein, 2010; Ricks, 2010; Pozsar et al, 2010).

\section{Porter Diamond Model}

In order to investigate why different nations gain competitive advantage in particular industries, Porter (1990) suggested the diamond model. Porter has used the diamond model when consulting with the governments of Canada (Porter \& the Monitor Company, 1991) and New Zealand (Crocombe, Enright, \& Porter, 1991). Porter's model evaluates why particular nations have competitive advantage in global competition. The diamond model consists of 


\section{Macrothink}

four determinants: factor conditions, demand conditions, related and supporting industries, and firm strategy, structure, and rivalry (Figure 1). These four determinants mutually affect each other and a change in one of them affects all other three determinants (Porter, 1990). In addition to these four determinants, government and chance can indirectly influence the competitiveness (Porter, 1990).

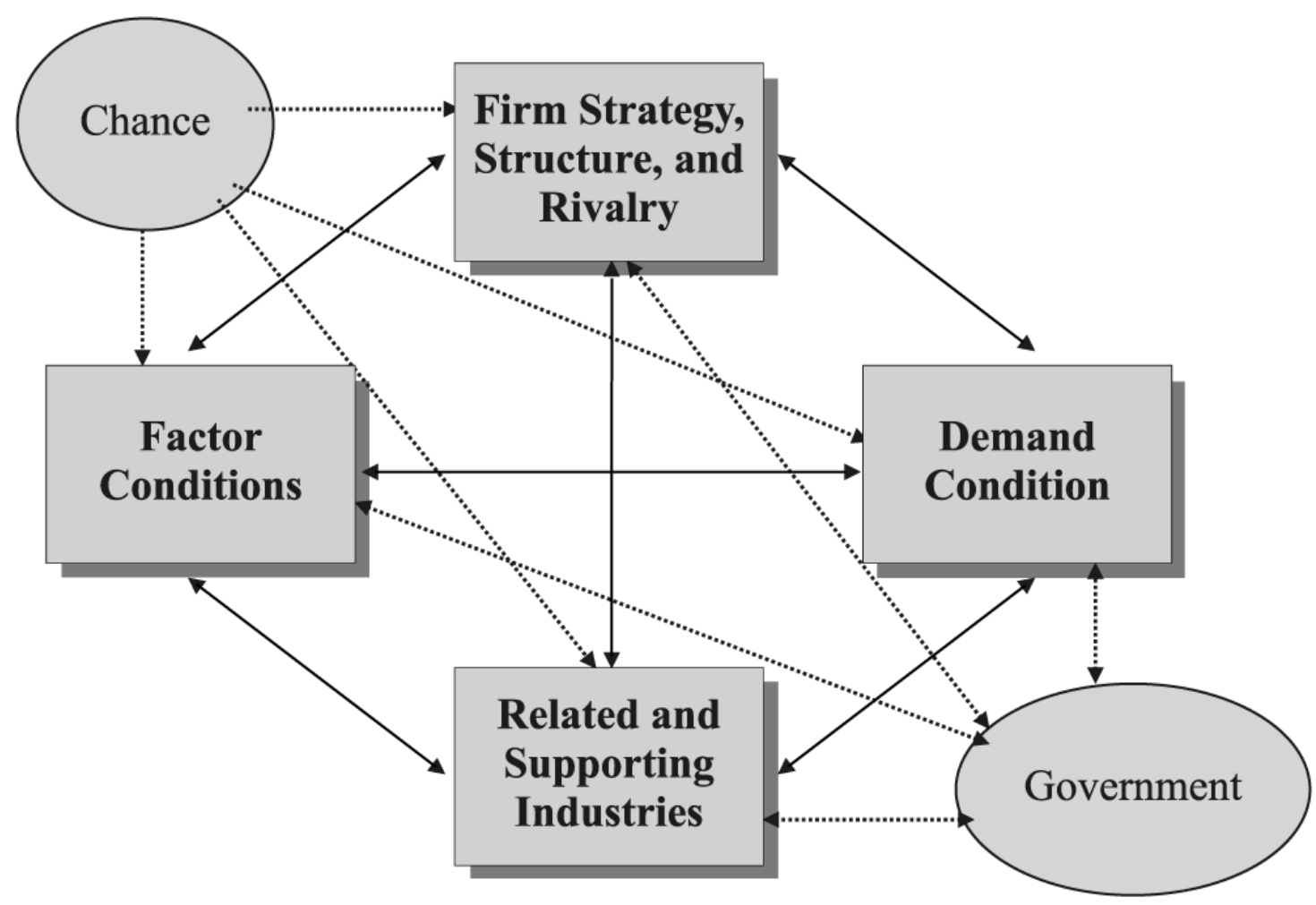

Figure 1. Porter Diamond Model (Source: Porter, 1990)

Factor conditions include raw materials, knowledge resources, physical resources, human resources, technological resources, capital resources, infrastructure, innovation power and manager's capabilities. Specialized resources are often specific for an industry and important for its competitiveness. Porter (1990) divides factor conditions into two groups: home-grown resources (e.g. raw material, energy, and unprofessional human resources) and highly specialized resources (e.g. technology, knowledge, and professional human resources). According to porter basic and generalized factors (i.e. home-grown resources) are easy to create, whereas advanced and specialized factors (i.e. highly specialized resources) are more decisive and provide sustainable basis for competitive advantage. Demand conditions determine the circumstances of domestic demand for products of an industry and an increase in demand has a great influence on competitiveness. Porter (1990) believes that a big growing domestic market will encourage the producers to develop their technologies and efficiency. He believes that this can be a competitive advantage for a nation. In contrast, small domestic 
markets have low economic growth rates and therefore they encourage the companies to look for exporting possibilities. Related and supporting industries refers to distributors and retailers, research organizations, product distribution systems, raw materials suppliers, equipment and tools, financial organizations such as banks and stock markets, transportation systems, and industries which use specific technology, and laboratory facilities. According to Porter (1990) the existence of strong related and supporting industries in a country is a vital determinant of competitive advantage. Firm's strategies, structures, and rivalry also play an important role in its competitiveness and can become a source of competitive advantage. In order to achieve competitive advantage Porter (1990) suggests public strategies. Based on these strategies, a firm can achieve competitive advantage in two ways: cost advantage (i.e. providing products and services with lower cost compared to rivals) and distinction advantage (i.e. providing a broad range of products and services with distinctive features). The existence of intense domestic rivalry is important because it will encourage the firms to become independent of basic factor advantages. Porter (1990) believes that although the role of government and chance in obtaining a competitive advantage is very important but these two have an indirect influence on competition by influencing the other four factors of competitive advantage.

Porter believes that these factors interact with each other in order to create conditions where innovation and competitiveness happens (Traill \& Pitts, 1998). Porter's diamond model has been criticized by many scholars (e.g. Rugman \& D'Cruz, 1993; Rugman \& Verbeke, 1993; Stopford \& Strange, 1991; Van den Bosch \& De Man, 1994; Van den Bosch \& Van Prooijen, 1992). Rugman (1992) claimed that a much more relevant concept prevails in small and open economies which is called the double diamond model. The double diamond model which was developed by Rugman and D'Cruz (1993) suggests that managers build upon both domestic and foreign diamonds in order to become competitive in global markets in terms of survival, profitability, and growth.

Many scholars have used Porter diamond model in their research (e.g. Al-Mamun et al, 2013; Amiri Aghdaie et al, 2012; Chen \& Ning, 2002; Chaabna \& Wang, 2015; Jin \& Moon, 2006; Hodgetts, 1993; Liu \& Song, 1997; Márkus, 2008; Yousefi, 2009). Chaabna and Wang (2015) investigated the state of e-commerce in Algeria and determined the nature of the barriers which prevent the country from growth and proposed some solutions based on Porter's diamond model. Al-Mamun et al. (2013), made an attempt to illustrate the status of ICT in Bangladesh using Porter's diamond model. Amiri Aghdaie et al. (2012) used Porter diamond model to identify the barriers to Iran's saffron exports to international markets in order to maintain Iran's position as the world's biggest producer and exporter of saffron and suggested some solutions for eliminating each of these barriers. Yousefi (2009) used this model for economic examination of the factors that affect e-commerce. Jin and Moon (2006) used Porter's diamond model and a generalized double diamond model in order to study the competitiveness of Korea's apparel industry. They suggested new sources of competitive advantage factors. Chen and Ning (2002) suggest a revised framework based on Porter's diamond model in order to examine the development of e-commerce industry in 


\section{Macrothink}

less-developed countries. In the current study we use diamond model to find the competitive advantages of shadow banking industry not a particular nation.

\section{Methodology}

The goal of this paper is to find the competitive advantages of shadow banking industry by using Porter diamond model. Because participants in a decision-making process tend to overstate their own influence (Atuahene-Gima \& Evangelista, 2000), the respondents chosen for this research were only senior managers, to whom staff from different areas within a business unit report. In order to choose a sample of 65 managers, stratified random sampling was used. The reason to use stratified random sampling was that subpopulations within the overall population varied. The sample included 22 bank managers, 20 portfolio managers, and 23 chief financial officers (CFO) from various firms. Figure 2 depicts the personal characteristics of questionnaire respondents.



Gender

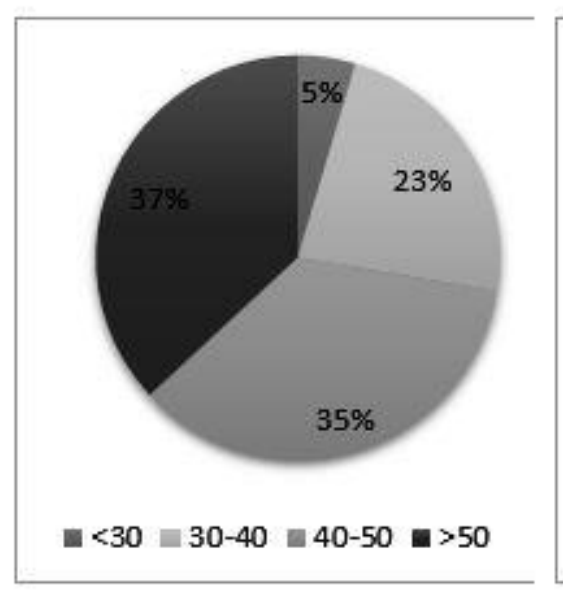

Age (years)

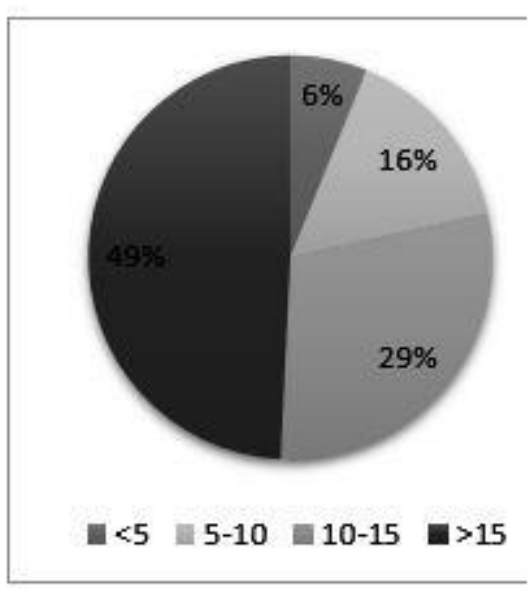

Job Experience (years)

Figure 2. Personal characteristics of the questionnaire respondents

(The figure shows the percentage of managers in each category)

In order to accept or reject the research's hypotheses, a questionnaire with 42 questions was created; each statement in the questionnaire was scored on a 7-point Likert scale (Likert, 1932) ranging from "strongly disagree" (1) to "strongly agree" (7). The study had six hypotheses:

1) Factor conditions contribute to the competitiveness of shadow banking industry.

2) Related and supporting industries contribute to the competitiveness of shadow banking industry.

3) Firm strategy, structure, and rivalry contribute to the competitiveness of shadow banking industry. 
4) Demand conditions contribute to the competitiveness of shadow banking industry.

5) Chance contributes to the competitiveness of shadow banking industry.

6) Governments contribute to the competitiveness of shadow banking industry.

To check the reliability of the research questionnaire, internal consistency and split-half methods were used. The Cronbach's alpha (Cronbach, 1951) was calculated with SPSS software. The questionnaire's Cronbach's alpha was 0.88, indicating suitable internal consistency and reliability. In the split-half analysis, results indicated that Cronbach's alpha was 0.89 for the first 21 questions of the questionnaire, and 0.86 for the latter 21 questions. Since the difference between the two amounts was not significant, the reliability of the questionnaire was accepted. In order to confirm the validity of the questionnaire, its content validity was examined. The content validity was unanimously accepted by a group of six experts including two finance professors, two bank managers and two CFOs.

In order to accept or reject the research's hypotheses, one-sample t-test was conducted with the use of SPSS software. One sample t-test assesses whether a sample value differs from the hypothesized value or not. In other words it measures whether the mean of a normally distributed population has a value specified in the null hypothesis. The one-sample t-test is used when we have a normal population or $n>30$ while $\sigma$ is unknown. In testing the null hypothesis that the populations mean is equal to a specified value $\mu_{0}$, one uses equation 1 .

$$
\mathrm{t}=\frac{\overline{\mathrm{x}}-\mu_{0}}{\mathrm{~s} / \sqrt{\mathrm{n}}}
$$

Equation 1.

Where $\bar{x}$ is the sample mean, $s$ is the sample standard deviation of the sample and $n$ is the sample size. The degrees of freedom used in this test was $n-1$. In order to calculate the amount of the sample standard deviation $(s)$, one uses equation 2 .

$$
s=\sqrt{\frac{1}{N-1} \sum_{i=1}^{N}\left(x_{i}-\bar{x}\right)^{2}}
$$

Equation 2.

Where $N-1$ equals the number of degrees of freedom in the vector of residuals $\left(x_{1}-\bar{x}, \ldots, x_{n}-\bar{x}\right.$ ) (Azar \& Momeny, 2010). Once a t-value is determined, a p-value can be found using a table of values from Student's t-distribution. If the calculated p-value is below the statistical significance level (0.05), then the null hypothesis (H0) is rejected in favor of the alternative hypothesis. In order to find the p-value we used two-tailed hypothesis testing.

Before performing the t-test, Kolmogorov-Smirnov test (KS test) was done in order to make sure that the data were normally distributed. For this test, the confidence level was set at 95 percent. According to KS test results the $\mathrm{P}$ for our data was equal to 0.34 . Since $\mathrm{P}=0.34$ is 
higher than 0.05 , the null hypothesis was accepted and it was concluded that our data followed a normal distribution with mean $=3.89$ and standard deviation=1.64.

\section{Results and Discussion}

Table 1 summarizes the results of hypothesis testing using one sample t-test. Based on the results of this study it can be concluded that factor conditions, chance and government do not contribute to the competitiveness of shadow banking industry. On the other hand the results suggested that related and supporting industries, firm strategy, structure and rivalry, and demand conditions contribute to the competitiveness of shadow banking industry.

Table 1. Results of hypothesis testing

\begin{tabular}{|c|c|c|c|c|c|}
\hline $\begin{array}{c}\text { Hypothesis } \\
\text { No. }\end{array}$ & DF & T-Value & P-Value & alpha & Result \\
\hline 1 & 64 & 3.75705 & 0.000374 & 0.05 & Reject null hypothesis \\
\hline 2 & 64 & 1.72068 & 0.090141 & 0.05 & Accept null hypothesis \\
\hline 3 & 64 & 0.57676 & 0.566127 & 0.05 & Accept null hypothesis \\
\hline 4 & 64 & 0.88282 & 0.380639 & 0.05 & Accept null hypothesis \\
\hline 5 & 64 & 2.78655 & 0.007003 & 0.05 & Reject null hypothesis \\
\hline 6 & 64 & 2.44156 & 0.017399 & 0.05 & Reject null hypothesis \\
\hline
\end{tabular}

Demand conditions contribute to the competitiveness of shadow banking industry because in many countries the demand for low interest rate financing exceeds the supply. Therefore many entrepreneurs need to find alternative sources of financing and a large group of them consider shadow banking as the best option. Another important factor that increases the demand for shadow banking is the relatively easiness of obtaining financing through this source. This is mainly because the shadow banking industry has less regulations compared to traditional financing sources like banks and financial markets. For instance obtaining a loan from a bank requires high levels of credit worthiness while individuals and firms without very high credit scores can get loans through shadow banking system much easier and at lower interest rates. Therefore we can claim that the demand for financing through shadow banking will remain high unless there are better sources of financing for individuals and firms with low credit scores.

The main rival of shadow banking industry is the traditional banking industry. One of the strategies of shadow banking industry is to provide loans with relatively lower interest rates compared to traditional banks. Another strategy of shadow banking is to provide financing to all types of business activities regardless of how risky they are. This strategy is related to the fact that shadow banking is less regulated and in many cases provides financing to individuals and firms who are unable to get loans from traditional financing channels. Although the strategy and structure of shadow banking industry contribute to its 
competitiveness, this industry is still considered to be vulnerable to unanticipated shocks because of its huge size, reluctance of investors for bearing risk and the role of securitization in increasing leverage (Gennaioli et al, 2013).

Related and supporting industries also contribute to the growth and competitiveness of shadow banking industry. Risky businesses rely on shadow banking because they may have difficulty in obtaining loans from traditional banks or raising money through financial markets can be impossible for them. Therefore the existence of risky businesses guarantees the growth of shadow banking industry. As the demand for starting highly risky businesses increases the demand for shadow banking also grows and shadow banking system becomes the main source of funding for those business activities. Shadow banking usually requires less collateral when giving loans to businesses while traditional banks request more valuable assets as collateral for their loans. Therefore new businesses can raise more money through shadow banking.

\section{Conclusion}

Shadow banking industry has competitive advantage over traditional banking industry due to its ability to provide low interest loans to risky businesses and providing loans with less collateral compared to traditional banks. Although shadow banking might have some benefits in growing economies it can cause systemic risk due to its unregulated activities and might increase the chances of a financial crisis. Therefore it is important to make the shadow banking activities more regulated in order to eliminate the systemic risk generated by this industry. The results of this study suggested that Porter diamond model can be used in order to find the competitive advantages of shadow banking industry. Finding the factors that contribute to the competitiveness of shadow banking has two important results: First, becoming familiar with competitive advantages of shadow banking helps governments to better understand the characteristics of this industry and can help them in regulating shadow banking activities. Second, traditional banks can become more familiar with the competitive advantages of shadow banking system and therefore can find better ways to compete with this growing industry.

\section{References}

Acharya, V. V., Schnabl, P., \& Suarez, G. (2013). Securitization without risk transfer. Journal of Financial economics, 107(3), 515-536. http://dx.doi.org/10.1016/j.jfineco.2012.09.004

Adrian, T., \& Ashcraft, A. B. (2012). Shadow banking regulation. Federal Reserve Bank of New York Staff Report, (559). http://dx.doi.org/10.2139/ssrn.2043153

Adrian, T., \& Shin, H. S. (2009). The Shadow Banking System: Implications for Financial Regulation. Banque de France Financial Stability Review, 13, 1-10.

Allen, F., Carletti, E., Qianc, J., \& Valenzuela, P. (2013) Financial Intermediation, Markets, and Alternative Financial Sectors. Handbook of the Economics of Finance, 2A, 759-798. 
Al-Mamun, M. A., Zayed, N. M., \& Hossain, M. S. (2013). Using Porter's diamond to determine the condition of ICT in a developing country: a study on Bangladesh. Electronic Commerce Research, 1(3), 138-150.

Amiri Aghdaie, S. F., Seidi, M., \& Riasi, A. (2012). Identifying the Barriers to Iran's Saffron Export by Using Porter's Diamond Model. International Journal of Marketing Studies, 4(5), 129-138. http://dx.doi.org/10.5539/ijms.v4n5p129

Atuahene-Gima, K., \& Evangelista, F. (2000). Cross-functional influence in new product development: An exploratory study of marketing and R\&D perspectives. Management Science, 46(10), 1269-1284.

Azar, A., \& Momeny, M. (2010). Statistics and Its Application in Management: (Vol 2): Statistical Analysis (Third edition). Tehran: The Organization for Researching and Composing University Textbooks in the Humanities.

Black, S., \& Munro, A. (2010). Why issue bonds offshore? Bank for International Settlements (BIS) Working paper, No. 334.

Chaabna, S., \& Wang, H. (2015). Analysis of the State of E-commerce in Algeria. International Journal of Marketing Studies, $7(2), \quad 44-58$. http://dx.doi.org/10.5539/ijms.v7n2p44

Chen, S., \& Ning, J. (2002). Constraints on e-commerce in less developed countries: the case of China. Electronic Commerce Research, 2(1-2), 31-42. http://dx.doi.org/10.1023/A:1013331817147

Claessens, S., \& Ratnovski, L. (2014). What Is Shadow Banking? IMF Working Paper 14/25, International Monetary Fund, Washington

Claessens, S., Pozsar, Z., Ratnovski, L., \& Singh, M. M. (2012). Shadow banking: economics and policy. IMF Staff Discussion Note SDN/12/12, International Monetary Fund, Washington.

Crocombe, F. T., Enright, M. J., \& Porter, M. E. (1991). Upgrading New Zealand's competitive advantage. Auckland: Oxford University Press.

Cronbach, L. J. (1951). Coefficient alpha and the internal structure of tests. Psychometrika, 16(3), 297-334. http://dx.doi.org/10.1007/BF02310555

Financial Stability Board (FSB). (2011). Shadow Banking: Scoping the Issues. (Retrieved on $8^{\text {th }} \quad$ March, 2015 from http://www.financialstabilityboard.org/2011/04/shadow-banking-scoping-the-issues/)

Gennaioli, N., Shleifer, A., \& Vishny, R. W. (2013). A model of shadow banking. The Journal of Finance, 68(4), 1331-1363. http://dx.doi.org/10.1111/jofi.12031

Gorton, G., \& Metrick, A. (2010). Regulating the shadow banking system. Brookings Papers 
on Economic Activity, 261-297.

Gorton, G., \& Metrick, A. (2012). Securitized banking and the run on repo. Journal of Financial Economics, 104(3), 425-451. http://dx.doi.org/10.1016/j.jfineco.2011.03.016

Gozzi, J. C., Levine, R., Peria, M. S. M., \& Schmukler, S. L. (2012). How firms use domestic and international corporate bond markets (No. w17763). National Bureau of Economic Research. http://dx.doi.org/10.3386/w17763

Greenwood, J., \& Smith, B. D. (1997). Financial markets in development, and the development of financial markets. Journal of Economic Dynamics and Control, 21, 145-181. http://dx.doi.org/10.1016/0165-1889(95)00928-0

Hodgetts, R. M. (1993). Porter's diamond framework in a Mexican context. MIR: Management International Review, 41-54.

International Monetary Fund (IMF). (2014). Shadow Banking Around The Globe: How Large, And How Risky? Global Financial Stability Report, October 2014.

Jin, B., \& Moon, H. C. (2006). The diamond approach to the competitiveness of Korea's apparel industry: Michael Porter and beyond. Journal of Fashion Marketing and Management: An International Journal, 10(2), 195-208. http://dx.doi.org/10.1108/13612020610667504

Levine, R., \& Zervos, S. (1998). Stock markets, banks, and economic growth. American Economic Review, 88, 537-558.

Likert, R. (1932). A Technique for the Measurement of Attitudes. Archives of Psychology, 140, $1-55$.

Liu, X., \& Song, H. (1997). China and the multinationals - a winning combination. Long Range Planning, 30(1), 74-83. http://dx.doi.org/10.1016/S0024-6301(96)00098-2

Márkus, G. (2008). Measuring company level competitiveness in Porter's Diamond model framework. In FIKUSZ 2008 Business Sciences-Symposium for Young Researchers: Proceedings, 149-158.

McCulley, P. (2007). Teton Reflections. Global Central Bank Focus Series, PIMCO, August/September.

McCulley, P. (2009). The shadow banking system and Hyman Minsky's economic journey. Insights into the Global Financial Crisis, 257-68.

Mehrling, P., Pozsar, Z., Sweeney, J., \& Neilson, D., (2013). Bagehot was a Shadow Banker: Shadow Banking, Central Banking, and the Future of Global Finance. Shadow Banking Colloquium, a project of the Financial Stability Research Program of the Institute for New Economic Thinking.

Noeth, B. J., \& Sengupta, R. (2011). Is shadow banking really banking?. The Regional 
Economist, Federal Reserve Bank of St. Louis, 10, 8-13.

Porter, M. E. (1990). The Competitive Advantage of Nations. New York, NY: The Free Press.

Porter, M. E., \& the Monitor Company (1991). Canada at the crossroads: The reality of a new competitive environment. Ottawa: Business Council on National Issues and Minister of Supply and Services of the Government of Canada.

Pozsar, Z., Adrian, T., Ashcraft, A. B., Boesky, H. (2010). Shadow Banking. Federal Reserve Bank of New York Staff Report, (458). http://dx.doi.org/10.2139/ssrn.1640545

Riasi, A. (2004). Introducing some of the most famous tourist attractions of Iran and the world, Mashhad: Sokhan Gostar Publication. http://dx.doi.org/10.13140/RG.2.1.1101.8088

Riasi, A. (2015). Barriers to international supply chain management in Iranian flower industry. Management Science Letters, 5(4), 363-368. http://dx.doi.org/10.5267/j.msl.2015.2.005

Riasi, A., \& Amiri Aghdaie, S. F. (2013). Effects of a Hypothetical Iranian Accession to the World Trade Organization on Iran's Flower Industry. Consilience: The Journal of Sustainable Development, 10(1), 99-110.

Riasi, A., \& Asadzadeh, N. (2015). The relationship between principals' reward power and their conflict management styles based on Thomas-Kilmann conflict mode instrument. Management Science Letters, 5(6), 611-618. http://dx.doi.org/10.5267/j.msl.2015.4.004

Riasi, A., \& Pourmiri, S. (2015a). Effects of online marketing on Iranian ecotourism industry: Economic, sociological, and cultural aspects. Management Science Letters, 5(10), 915-926. http://dx.doi.org/ 10.5267/j.ms1.2015.8.005

Riasi, A., \& Pourmiri, S. (2015b). Examples of Unsustainable Tourism in Middle East. Working Paper.

Ricks, M. (2010). Shadow banking and financial regulation. Columbia Law and Economics Working Paper, (370).

Rugman A. M., \& Verbeke, A. (1993). Foreign subsidiaries and multinational strategiec management: and extension and correction of Porter's single diamond framework. Management International Review, (Special Issue 2), 71-84.

Rugman, A. M. (1992). Porter takes the wrong turn. Business Quarterly, 56(3), 59-64.

Rugman, A. M., \& D'Cruz, J. R. (1993). The double diamond model of international competitiveness: Canada's experience. Management International Review, 33(2), 17-39.

Schwarcz, S. L. (2012). Regulating Shadow Banking. Review of Banking and Financial Law, 31(1). http://dx.doi.org/10.2139/ssrn.1993185

Singh, M. (2010). The Sizable Role of Rehypothecation in the Shadow Banking System, International Monetary Fund (IMF), Working Paper No. 10/172. 
http://dx.doi.org/10.2139/ssrn.1670740

Stein, J. C. (2010). Securitization, shadow banking \& financial fragility. Daedalus, 139(4), 41-51. http://dx.doi.org/10.1162/DAED_a_00041

Stopford, J. M., Strange, S. (1991) Rival states, rival firms: competition for world market shares. Cambridge: Cambridge University Press.

Traill, W. B., \& Pitts, E. (1998). Competitiveness in the Food Industry. Springer.

Van den Bosch, F. A. J. \& Van Prooijen, A. A. (1992). The competitive advantage of European nations: the impact of national culture - a missing element in Porter's analysis?, $\begin{array}{llrl}\text { European } \quad \text { Management } & \text { Journal, } & \text { 10(2), }\end{array}$ http://dx.doi.org/10.1016/0263-2373(92)90066-D

Van den Bosch, F. A. J., \& De Man, A. (1994). Government's impact on the business environment and strategic management. Journal of General Management, 19(3), 50-9.

Yousefi, A. (2009). An Economic Framework for the Assessment of E-Commerce in Developing Countries. In K. Rouibah, O. Khalil, \& A. Hassanien (Eds.) Emerging Markets and E-Commerce in Developing Economies (pp. 255-270). Hershey, PA: Information Science Reference. http://dx.doi.org/10.4018/978-1-60566-100-1.ch012

\section{Copyright Disclaimer}

Copyright for this article is retained by the author(s), with first publication rights granted to the journal.

This is an open-access article distributed under the terms and conditions of the Creative Commons Attribution license (http://creativecommons.org/licenses/by/3.0/). 